\title{
Role of circulating microRNAs in acute appendicitis
}

\author{
Avni Uygar Seyhan, M.D., ${ }^{1}$ Elif Funda Şener, M.D., ${ }^{2}$ Oğuzhan Bol, M.D., ${ }^{3}$ Serpil Taheri, M.D., ${ }^{2}$ \\ Tugba Topaloglu, M.D., ${ }^{4}$ Esra Tufan, M.D., ${ }^{4}$ Reyhan Tahtasakal, M.D., ${ }^{4}$ \\ Nahide Ekici Günay, M.D., ${ }^{5}$ Hatice Karabulut, M.D., ${ }^{6}$ Nurullah Günay, M.D. ${ }^{6}$
}

\begin{abstract}
${ }^{1}$ Department of Emergency Medicine, Health Sciences University, Kartal Dr. Lütfi Kirdar Training and Research Hospital, İstanbul-Turkey ${ }^{2}$ Department of Medical Biology, Erciyes University Faculty of Medicine, Kayseri-Turkey

${ }^{3}$ Department of Emergency Medicine, Namık Kemal University Faculty of Medicine, Tekirdağ-Turkey

${ }^{4}$ Genome and Stem Cell Center (GENKOK), Erciyes University, Kayseri-Turkey

${ }^{5}$ Department of Clinical Biochemistry, Health Sciences University, Kayseri Training and Research Hospital, Kayseri-Turkey

${ }^{6}$ Department of Emergency Medicine, Erciyes University Faculty of Medicine, Kayseri-Turkey
\end{abstract}

\begin{abstract}
BACKGROUND: Acute appendicitis (AA) is a momentous, emergency, surgical pathology that has still been investigated for both etiopathogenetic unknowns and challenges in diagnosis. Presently, there is little information about the role of microRNAs (miRNAs), which have basic biological functions in the cell, can be a marker, and are associated with various pathologies, in patients with AA. The aim of this study was to investigate the expressions of some miRNAs in AA.
\end{abstract}

METHODS: Overall, 4I miRNAs were screened in 48 individuals comprising 24 patients with AA and 24 healthy controls at Erciyes University Genome and Stem Cell Center (GENKOK). The obtained data were analyzed using appropriate statistical methods.

RESULTS: miR-29c-3p was found to be increased 2-fold during the first 4-6 h in AA, and this increase was revealed to be statistically significant compared with healthy individuals. Similarly, expressions of let-7b-5p, let-7i-5p, miR-30a-5p, miR-29b-3p, and miR-23a-3p also increased approximately 2 -fold in AA, although not statistically significant. No significant differences were found in the screening of the remaining 35 miRNAs in patients with AA.

CONCLUSION: Although there is little information about the relationship between AA and miRNAs currently, miR-29c-3p was reported to increase in the acute period of AA in this study. With the current results, it can be argued that miR-29c-3p bears the potential to be a marker in patients with AA. The present study may also be a basic research for more extensive and necessary miRNAs screening in this field.

Keywords: Acute appendicitis; inflammation; microRNAs.

\section{INTRODUCTION}

New horizons can be established to directed to its diagnosis and treatment via a new and different researches related to AA that is still an unknown of its definitive etiopathogenesis; AA carries a $6 \%-7 \%$ risk of development in human beings during their lifetime. ${ }^{[l]}$ As a new and different point of view, the present study aimed to challenge the possible relationship be- tween microRNAs (miRNA) and AA that is yet still unknown. The number of miRNAs, which were detected in the 1990s and new ones have been discovered so far, in humans is about 1880. ${ }^{2]}$ Currently, there are little data to conclude whether these groups of molecular biologic entities that are known to take part in the regulation of many cellular functions and for example as oncogene or tumor suppressors or not have a role in the etiopathogenesis of AA. There is only one report show-

Cite this article as: Seyhan AU, Şener EF, Bol O, Taheri S, Topaloglu T, Tufan E, et al. Role of circulating microRNAs in acute appendicitis.

Ulus Travma Acil Cerrahi Derg 2018;24:211-215.

Address for correspondence: Nurullah Günay, M.D.

Erciyes Üniversitesi Tıp Fakültesi, Acil Tıp Anabilim Dalı, Kayseri, Turkey

Tel: +90 352 - 2076666 E-mail: ngacil@hotmail.com

Ulus Travma Acil Cerrahi Derg 2018;24(3):21 I-215 DOI: 10.5505/tjtes.2017.22379 Submitted: 13.07.2017 Accepted: 13.09.2017 Online: 10.05.2018

Copyright 2018 Turkish Association of Trauma and Emergency Surgery 
ing no relation between $A A$ and $\operatorname{miR}-2 \mid{ }^{[3-6]}$ It is suggested that miRNAs that do not encode proteins in terms of genetics but take part in cellular metabolism by regulating protein expression play a role in various pathologies; for example, miR-I46a and miR-223 levels have been reported to be low in sepsis. ${ }^{[7]}$ In addition to their role in elementary biological functions and as a biological marker, they are considered to create a therapeutic pathway by affecting a specific gene target by changing the expression of miRNAs. ${ }^{[4,5]}$ It is still early to generate a miRNAmediated therapeutic hypothesis in patients with $A A$, but it is possible to screen some miRNAs in AA. This probability is the aim of this present study.

\section{MATERIALS AND METHODS}

This study was conducted in cooperation with Kayseri Training and Research Hospital Emergency Department, Erciyes University Medical Faculty Emergency Medicine Department and Medical Biology Departments. The present study was approved by the local ethics committee (10.02.20I5/44I), and the support by the Scientific Research Project numbered TTU-2016-6072 was terminated on 01.30.2017. MiRNA analyses were performed at the GENKOK of the same university. The project budget was the main determinant in the detection of 41 miRNAs scanned in a total of 48 individuals, including the study and control groups.

\section{Patient Selection}

Patients with AA are carefully selected among cases presenting to the emergency service of a hospital where around 8-10 emergency appendectomies are performed daily. A total of 24 patients with AA could have been included in the study as per the project budget; hence, cases that were almost certainly clinically diagnosed as AA and have a positive finding by computed tomography were included in the study. In addition, patients complaining of AA symptoms since 4-6 h were selected as the target study group. No pediatric cases were included in the study because the pediatric emergency service functions as a separate unit. Subsequently, pathologic diagnosis confirmed the diagnosis of AA in all cases. During the establishing of the study group, cases with any systemic disease, chronic drug use, and even presence of any suspicion for an additional pathology were excluded from the study. In summary, although the patients with AA have been defined by the method used in a previous study, a more sensitive approach has been exhibited and patients in the 4-6-h period after the start of AA symptomatology have been selected. ${ }^{[8]}$ Control group samples were obtained at blood center from healthy subjects whose age and gender concordant with the study group.

\section{Serum Samples Collection and Preparation}

From each patient and control subject, $5 \mathrm{ml}$ of venous blood samples was obtained, centrifuged at $3000 \times g, 4^{\circ} \mathrm{C}$, and for 20 min and then serum was separated. All serum samples were stored at $-80^{\circ} \mathrm{C}$ for later analysis.

\section{RNA Extraction and qRT-PCR for miRNA Expressions}

Total RNA, including miRNAs, was extracted from sera samples of patients and controls using the miRNeasy Mini Kit (Qiagen, Germany, Cat. No.2 17004). RNA (50 ng) was reverse transcribed using a miScript II RT Kit (Qiagen, Cat. No.2l8I6I) in a Qiagen SensQuest Lab cycler (Qiagen, Germany), according to the manufacturer's protocol. Complementary DNA (cDNA) was then diluted in RNase-free water. Quantitative real-time PCR (qRT-PCR) was performed using miScript Syber Green PCR kit (Qiagen, Cat. No.218075). Gene expression profiles were generated in 96-well arrays using the custom miScript miRNA PCR array, according to manufacturer's instructions, for the following $4 \mathrm{I}$ microRNAs: Hs_let-7b-5p, Hs_let-7c, Hs_let-7d-5p, Hs_let-7i-5p, Hs_miR29a-3p, Hs_miR-29c-3p, Hs_miR-30b-5p, Hs_miR-34a-5p, Hs_miR-98, Hs_miR-38I, Hs_miR-449a, Hs_miR-449b-5p, Hs_miR-590-5p, Hs_miR-656, Hs_let-7f-5p, Hs_miR-29b-3p, Hs_miR-18Ib-5p, Hs_miR-30a-5p_I, Hs_let-7g-5p, Hs_miR10I-3p, Hs_miR-128, Hs_miR-18Ia-5p, Hs_miR-I8Ic-5p, Hs_miR-202-3p, Hs_miR-2l-5p, Hs_miR-30c-5p, Hs_miR30d-5p, Hs_miR-30e-5p, Hs_miR-374a-5p, Hs_miR-543, Hs_ miR-875-3p_I, Hs_miR-548e, Hs_miR-I44-3p, Hs_let-7a-5p, Hs_let-7e-5p, Hs_miR-I8Id, Hs_miR-23a-3p, Hs_miR-23b3p, Hs_miR-300, Hs_miR-340-5p, and Hs_miR-524-5p. Qiagen Rotor-Gene $\mathrm{Q}$ system were used as follows: $15 \mathrm{~min}$ at $95^{\circ} \mathrm{C}$ for I cycle and $15 \mathrm{~s}$ at $94^{\circ} \mathrm{C}, 30 \mathrm{~s}$ at $55^{\circ} \mathrm{C}$, and $30 \mathrm{~s}$ at $70^{\circ} \mathrm{C}$ for 40 cycles. The controls were used when the differential expression of miRNAs was investigated using commercially available single primer assays (Qiagen, USA) samples with (i) No RNA, (ii) No reverse transcriptase and (iii) $C$. elegans spike-controls in cDNA synthesis and (iv) No cDNA control in the reaction. Threshold cycle data were analyzed using the RT2 Profiler software (version 3.4; SABiosciences). Relative gene expression levels were normalized to housekeeping genes (SNORD6I, Hs_RNU6-2_II). The $2 \Delta \triangle C T$ method of relative quantification was used to calculate the relative abundance of miRNAs in serum.

\section{Statistical Analysis}

The relative expression of miRNAs was analyzed using SABiosciences software, and the $\mathrm{P}$-value was calculated based on Student's t-test of the replicate $2 \Delta \Delta C T$ (-Delta $C t$ ) values for each gene in the control and patient groups. P-values $<0.05$ were considered statistically significant. The relevant clinicopathological features were determined by one way ANOVA for quantitative data and $X^{2}$ test for qualitative data. All tests were two-sided, and $\mathrm{p}$-value $<0.05$ was considered statistically significant.

\section{RESULTS}

The study and control groups consisted of 48 individuals from the same number and gender. The mean ages of subjects in the study and control groups were $33.00 \pm \mid 3.82$ and $33.50 \pm|3.7|$ 
years, respectively. All patients in the study group were found to have AA favorable CT imaging in the emergency department, and no other pathology was found; the pathologic results after appendectomy were consistent with $A A$.

Based on the miRNA analyses that constituted the main part of the study, it was determined that six of the 41 miRNAs demonstrated about two-fold increase in expression, whereas the remaining 35 miRNAs did not vary in patients with AA.

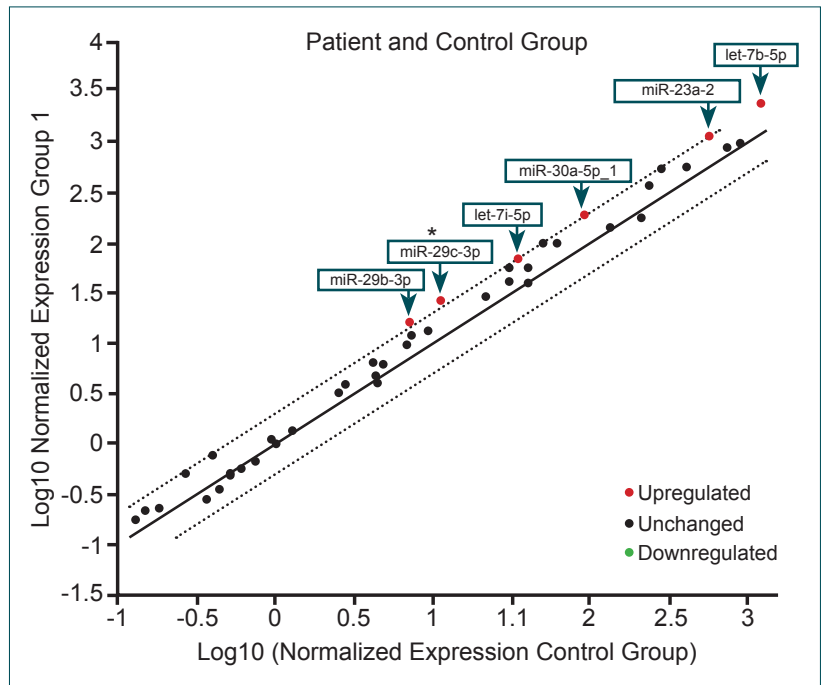

Figure 1. miRNAs scatter plot graph for groups.
Table I. Differential expression of the studied miRNAs in AA group compared with the control group

\begin{tabular}{lccc}
\hline Gene symbol & Fold change & $\mathbf{p}$ & $\mathbf{9 5 \%} \mathbf{C l}$ \\
\hline let-7b-5p & 2.015 & $0.08594 \mathrm{I}$ & $0.85,3.18$ \\
let-7i-5p & 2.0006 & 0.236203 & $0.54,3.47$ \\
miR-29c-3p & 2.3778 & 0.034991 & $0.39,4.36$ \\
miR-29b-3p & 2.3089 & 0.110923 & $0.28,4.33$ \\
miR-30a-5p & 2.1094 & 0.070602 & $0.61,3.61$ \\
miR-23a-3p & 2.0006 & 0.099282 & $0.64,3.36$ \\
\hline
\end{tabular}

The increased expression of miR-29c-3p, which was approximately doubled in patients with AA compared with healthy individuals, was found to be statistically significant $(p=0.034)$. There was no statistically significant increase in miRNAs encoded with let-7b-5p, let-7i-5p, miR-30a-5p, miR-29b-3p, and miR-23a-3p among the groups (Table I). When comparing AA patients with healthy individuals, it was found that other scanned miRNAs did not demonstrate any difference in expression levels among the groups. Scatterplot and heatmap graphics of all miRNAs are presented in Figures I and 2.

Additionally, it was set that there is no statistically significant variation in terms of gender of miR-29c-3p, which is detected elevated in patients with AA compared to healthy

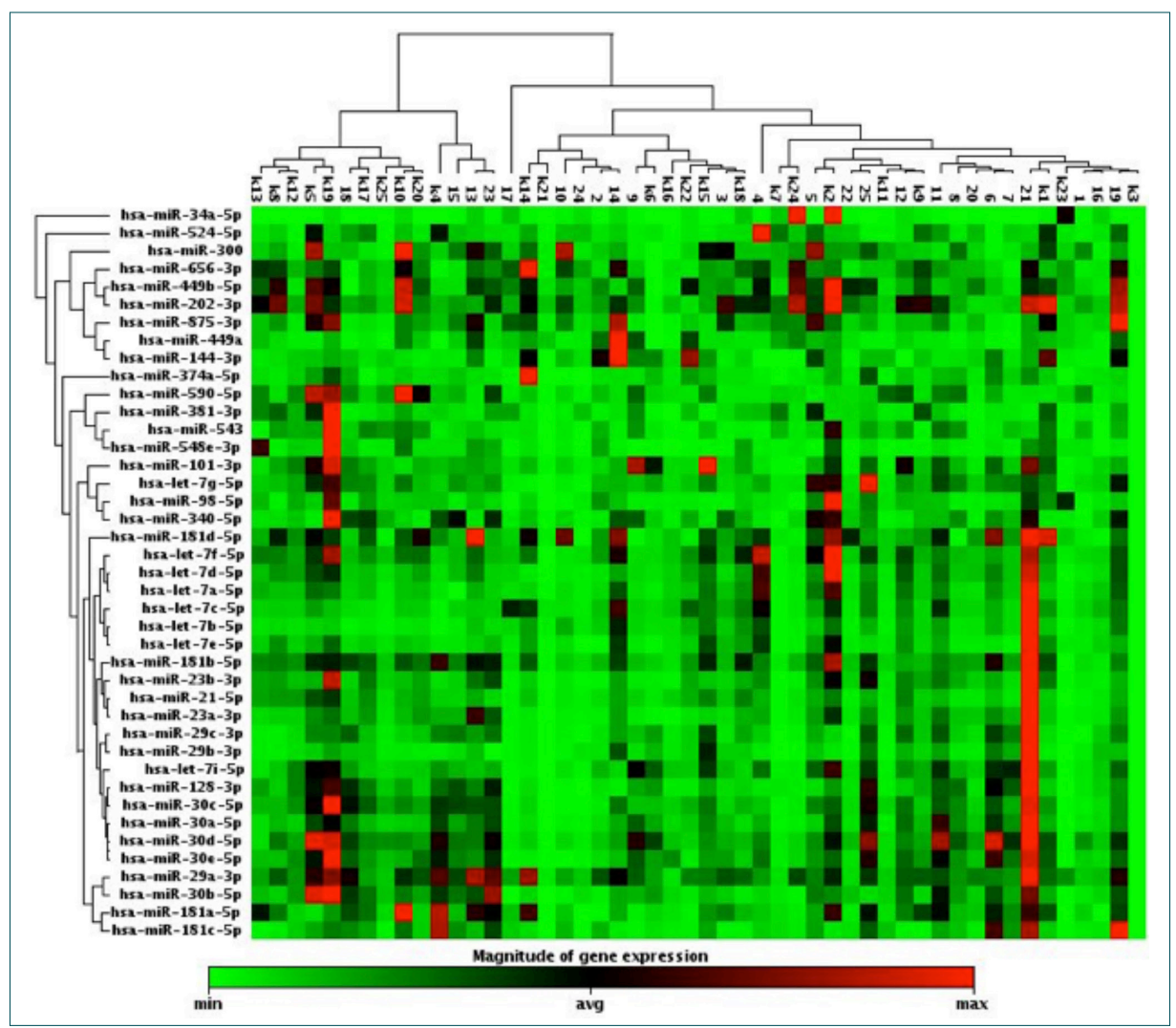

Figure 2. Heatmap graphic. 
Table 2. Potential inflammatory gene targets of identified miRNAs in patients with AA

\section{Potential marker of elevated miRNAs in AA}

let-7b-5p

let-7i-5p

miR-23a-3p

miR-29c-3p*

miR-29b-3p

miR-30a-5p
Potential inflammatory gene targets of identified miRNAs

ACVR2A, CCL7, CCR7, FASLG, GDF6, ILI0, ILI3, LY75, OSMR, POU2F2, TGFBR I

ATRN, CCL7, CXCLI2, ILI2B, IL6R, KITLG, M6PR, PROK2, TGFBR2, TPST I

CD276, HDAC4, ILIRAP, LIF, PTX3, TNFRSFIA, VEGFA

ACVRI, ATRN, ILIA, LEPR, LIFR, NR4A2

*Statistically significant.

individual. Furthermore, no correlation was detected between miR-29c-3p and abdominal pain, nausea, vomiting, loss of appetite, complete blood count, and some serum parameters.

\section{DISCUSSION}

It is stated that AA has still been primarily in the differential diagnosis of all age and gender patients presenting to the emergency departments with complaints of inflammatory abdominal pain, which is the leading cause of emergency surgery. AA is still under investigation because its early diagnosis and treatment is challenging. Currently, it is known that early and accurate diagnosis of $A A$ is indispensable in terms of not to be delaying of its treatment. Besides, it is extremely important to be able to prevent the undesirable morbimortality that negative laparotomy can cause. ${ }^{\left[{ }^{9]}\right.}$ The present study, performed with the consideration that miRNAs in AA might have a positive contribution to both concerns, yielded some positive results despite its limited budget.

This is the first study to characterize changes in AA with profiling of the selected miRNAs associated with inflammation. Our results revealed upregulation of miR-29c-3p, miR-23a$3 p$, miR-29b-3p, miR-30a-5p, let-7i-5p, and let-7b-5p in the AA group compared with the control group.

We found that miR-29c-3p could be used as a potential molecular marker to identify AA diagnosis with significant $p$-values $(p=0.035)$. We identified the possible miR-29c-3p molecular targets, which include CD276, HDAC4, ILIRAP, LIF, PTX3, TNFRSFIA, and VEGFA (Table 2).

In literature, miR-29c-3p is defined as a tumor suppressor gene. MiR-29c-3p is reported to regulate the P53 expression in particular. In the study by Galani et al., ${ }^{[10]}$ miRNA profiles have been investigated in benign, atypical, and malignant meningioma groups. Therefore, in meningiomas, miR-29c$3 p$, miR-200a, miR-I45, miR-219-5p have been reported to be downregulated, whereas miR-2I, miR-335, and miR-190a have been reported to be upregulated. Another study reported that the recurrence rates are lower in meningioma patients with low mir-29c-3p expression.
Geng Chen et al. ${ }^{[12]}$ reported that miR-29c-3p is expressed in almost any type of cancer. Pleckstrin homology-like domain family B member 2 (PHLDB2) gene is a valid target gene for mir-29c-3p as well. It was demonstrated that the inhibition of PHLDB2 gene by miR-29c-3p gene suppresses cell growth significantly in colon cancer in the presence of ectopic PHLDB2 expression. Therefore, mir-29c-3p is directly associated with $\mathrm{p} 53$ gene in colon cancer metastasis, and PHLDB2 is an important target gene for mir-29c-3p expression. Cells with an inactive p53 gene have low mir-29c3 p expression. ${ }^{[1]}$

In the study by Liu et al., miR-29c-3p is reported to be associated with vascular endothelial growth in cancer patients. In another study, RNA from tissues of $\mathbf{8 7}$ individual lung cancer patients was isolated, and I 105 miRNA expression profiles known for humans have been demonstrated. Eventually, it was determined that mir-29c-3p gene downregulation is negatively related to the sustainability of the disease in cancer patients. ${ }^{[13]}$

AA is an inflammatory emergency situation, which manifests by acute abdominal pain. As a result of the study we conducted, when the data from patients with AA were compared with those from healthy controls, miR-29c-3p expression was found out to be significantly higher. When the studies conducted till date were investigated, miR-29c-3p was reported to be associated with cancer. However, miRNA expression profiles in AA have not been investigated yet. As it has already been established, a specific miRNA can control more than 100 genes at once. Till date, the association between miR-29c-3p and AA has not been demonstrated in literature. $A A$ is an inflammatory and painful condition, in which patients usually present to the emergency services. Patients can present to emergency services with symptoms or with serious complications varying from simple pain to symptoms of perforation such as fever, vomiting, and abdominal rigidity. Because the disease's clinical window is broad, the rates of negative appendectomy have been reported to be high. Therefore, early and precise diagnosis of $A A$ is important. mir-29c-3p can be a marker for the necessity of early diagnosis and treatment of $\mathrm{AA}$. 


\section{Conclusion}

In conclusion, this is the first study to report the expression profiles of selected miRNAs in AA. It is suggested that miRNA-29c-3p levels are elevated in the first 4-6 h after the beginning of symptoms in patients with AA.

\section{Acknowledgment}

This study was supported by a project (TTU-2016-6072) from the Scientific Research Projects Department of Erciyes University, Kayseri.

\section{Conflict of interest: None declared.}

\section{REFERENCES}

1. Baird DLH, Simillis C, Kontovounisios C, Rasheed S, Tekkis PP. Acute appendicitis. BMJ 2017;357:j1703. [CrossRef]

2. Homo sapiens miRNAs (1917 sequences) [GRCh38]. Available at: http://www.mirbase.org/cgi-bin/mirna_summary.pl?org=hsa. Accessed Mar 26, 2018.

3. Menéndez P, Villarejo P, Padilla D, Palomino T, Nieto P, Menéndez JM, et al. Serum microRNA-21 usefulness in inflammatory pathology of the colon. Rev Gastroenterol Mex 2013;78:70-4. [CrossRef]

4. Zhang L, Huang J, Yang N, Greshock J, Megraw MS, Giannakakis A, et al. microRNAs exhibit high frequency genomic alterations in human cancer. Proc Natl Acad Sci U S A 2006;103:9136-41. [CrossRef]

5. Zekri ARN, Youssef ASED, Lotfy MM, Gabr R, Ahmed OS, Nassar A, et al. Circulating Serum miRNAs as Diagnostic Markers for Colorectal Cancer. PloS One 2016;11:e0154130. [CrossRef]

6. Le Quesne J, Caldas C. Micro-RNAs and breast cancer. Mol Oncol 2010;4:230-41. [CrossRef]

7. Wang JF, Yu ML, Yu G, Bian JJ, Deng XM, Wan XJ, et al. Serum miR$146 \mathrm{a}$ and miR-223 as potential new biomarkers for sepsis. Biochem Biophys Res Commun 2010;394:184-8. [CrossRef]

8. Taşlidere B, Şener EF, Taşlidere E, Ekici Günay N, Bol O, Bülbül E, et al. Role of endothelial nitric oxide synthases system on acuteappendicitis. Ulus Travma Acil Cerrahi Derg 2016;22:338-43.

9. Ceresoli M, Zucchi A, Allievi N, Harbi A, Pisano M, Montori G, et al. Acute appendicitis: Epidemiology, treatment and outcomes- analysis of 16544 consecutive cases. World J Gastrointest Surg 2016;8:693-9.

10. Galani V, Lampri E, Varouktsi A, Alexiou G, Mitselou A, Kyritsis AP. Genetic and epigenetic alterations in meningiomas. Clin Neurol Neurosurg 2017;158:119-25. [CrossRef]

11. Liu L, Bi N, Wu L, Ding X, Men Y, Zhou W, et al. MicroRNA-29c functions as a tumor suppressor by targeting VEGFA in lung adenocarcinoma. Mol Cancer 2017;16:50. [CrossRef]

12. Chen G, Zhou T, Li Y, Yu Z, Sun L. p53 target miR-29c-3p suppresses colon cancer cell invasion and migration through inhibition of PHLDB2. Biochem Biophys Res Commun 2017;487:90-5. [CrossRef]

13. Li X, Zhuang X, Xu T, Mao M, Wang C, Chen Y, et al. Expression analysis of microRNAs and mRNAs in ovarian granulosacells after microcystin-LR exposure. Toxicon 2017;129:11-9. [CrossRef]

\title{
ORIJINAL ÇALIŞMA - ÖZET
}

\section{Akut apandisitte dolaşımdaki mikroRNA'lar \\ Dr. Avni Uygar Seyhan, ${ }^{1}$ Dr. Elif Funda Şener, ${ }^{2}$ Dr. Oğuzhan Bol, ${ }^{3}$ Dr. Serpil Taheri, ${ }^{2}$ Dr. Tugba Topaloglu, ${ }^{4}$ Dr. Esra Tufan, ${ }^{4}$ Dr. Reyhan Tahtasakal, ${ }^{4}$ Dr. Nahide Ekici Günay, ${ }^{5}$ Dr. Hatice Karabulut, ${ }^{6}$ Dr. Nurullah Günay ${ }^{6}$}

\author{
${ }^{1}$ Sağlık Bilimleri Üniversitesi, Kartal Dr. Lütfi Kırdar Eğitim ve Araştırma Hastanesi, Acil Tıp Kliniği, İstanbul \\ ${ }^{2}$ Erciyes Üniversitesi Tıp Fakültesi, Tıbbi Biyoloji Anabilim Dalı, Kayseri \\ ${ }^{3}$ Namık Kemal Üniversitesi Tıp Fakültesi, Acil Tıp Anabilim Dalı, Tekirdağ \\ ${ }^{4}$ Erciyes Üniversitesi, Genom ve Kök Hücre Merkezi (GENKÖK), Kayseri \\ ${ }^{5}$ Sağlık Bilimleri Üniversitesi, Kayseri Eğitim ve Araştırma Hastanesi, Tıbbi Biyokimya Kliniği, Kayseri \\ ${ }^{6}$ Erciyes Üniversitesi Tıp Fakültesi, Acil Tıp Anabilim Dalı, Kayseri
}

AMAÇ: Akut apandisit (AA) gerek tanı anında yaşanan güçlükler nedeniyle gerekse de etiyopatogenetik bilinmeyenler açııından halen araştırılmaya devam eden önemli bir acil cerrahi patolojidir. Hücrede temel biyolojik işlevleri olan, biyolojik bir belirteç olabilen ve çeşitli patolojiler ile ilişkilendirilmiş mikroRNA'ların (miRNA) AA'lı hastalardaki rolü hakkında bugün için yeterli bir veri bulunmamaktadır. Bu çalışma ile bazı miRNA'ların AA'daki ekspresyonlarını araştırmak amaçlanmıştır.

GEREÇ VE YÖNTEM: Erciyes Üniversitesi Genome and Stem Cell Center (GENKOK) Merkezi'nde 24 AA'lı ve 24 sağlıklı toplam 48 bireye ait numunelerde 4 I miRNA'nın real time PCR ile taraması yapıldı. Elde edilen veriler uygun istatistiksel testlerle değerlendirildi.

BULGULAR: Akut apandisitli hastaların ilk dört-altı saatlik döneminde miR-29c-3p iki kat arttı, bu yükselme sağlıklı bireylere göre istatistiksel açıdan anlamlı bulundu. Benzer şekilde let-7b-5p, let-7i-5p, miR-30a-5p, miR-29b-3p ve miR-23a-3p ekspresyonları da AA'da yaklaşık iki kat artış gösterdi, ancak istatistiksel açıdan anlamlıık saptanmadı. Geri kalan 35 miRNA taramasında, AA'lı hastalar için özellik tespit edilmedi.

TARTIŞMA: Akut apandisit ve miRNA arasındaki ilişki hakkında şimdiye kadar elde edilmiş yeterli veri olmamasına rağmen, mevcut araştırmaya göre AA'lı hastalarda akut dönemde miR-29c-3p'nin yükseldiği tespit edilmiştir. Elde edilen bu veri ile miR-29c-3p'nin AA'lı hastalarda bir belirteç olabilme potansiyeli taşıdığı ileri sürülebilecektir. Bu çalışmanın, alanında ihtiyaç duyulan daha geniş miRNA taramalarına temel bir araştırma olabileceği de düşünülmüştür.

Anahtar sözcükler: Akut apandisit; enflamasyon; mikroRNA.

Ulus Travma Acil Cerrahi Derg 2018;24(3):21।-2I5 doi: 10.5505/tjtes.2017.22379 